\title{
Albania between Western Balkans Regionalization and European Integration
}

\author{
Dr. Ilir Kalemaj
}

University of New York Tirana; ikalemaj@unyt.edu.al

\section{Doi:10.5901/mjss.2016.v7n6p281}

\section{Abstract}

\begin{abstract}
Different local observers like Koneska (2007), Bechev (2011) and others have argued that there is a missing regional identity in the Southeastern Europe region, where both leaders and masses are reluctant to identify with the (Western) Balkan label, which is often connected to corruption, state capture, organized crime and other remedies that are deemed simultaneous obstacles to the path of democratization, rule of law and the EU integration. Albania, because of its idiosyncratic characteristics, it escaped unscathed the (former) Yugoslav wars and has not faced identity and nation-building challenges like its Western Balkan neighbors. These characteristics include inter alia the ethnic homogeneity and mass migration after the isolation of Communism. However, Albania has been part of the same web, with the same transition difficulties as its immediate Balkan neighbors. Because of these reasons, as well as geographical, historical and cultural, the regional identity that would have fostered a more sustainable regional cooperation between Albania and some of its neighbors has ranged from problematic to non-existent, with only recent glimpses of hope for future relations that would seek to create a notion of regional community. These include both top-dawn efforts, ranging from the series of meetings between Albania's premier Rama and his Serbian counterpart Vucić, trying to normalize the relations between the two countries, to projects such as the Balkan Union or "Balkan Schengen", although they still are at the level of initiative and remain to be materialized. Other projects include bottomup drives, such as the "Balkan Benelux" or trade networks such as CEFTA, with limited results. The EU's conditionality approach has been instrumental in the process, complimenting the U.S., NATO and other international actors' role in the process of ameliorating the neighbor relations in the region and moving fast ahead with regional cooperation, hopping that it would foster a regional identity in the near future. The present paper concentrates on how regional cooperation has affected Albania and its relations with the Western Balkan neighbors and what is to be expected in the near future.
\end{abstract}

Keywords: Albania, democratization, Western Balkans, regionalism, European integration.

\section{Introduction}

The Yugoslav dismemberment and the following ethnic conflict, has prevented not only the creation of a common regional identity that would replace the socialist (Yugoslav) one and would be more inclusive of the other national groups in the region, but also prevented the birth of a normal way of conducting business among the various Western Balkan states. Although the term Western Balkans has been disputed from its inception till now as well as its geographical and political ramifications, the area that includes all former Yugoslav Republics, minus Slovenia, plus Albania has been often a reference point for political instability, widespread corruption and penetration of organized crime, dysfunctional economies, as well as problems with property laws and law enforcement, lack of depoliticization of public administration etc., altogether inter-ethnic and inter-religious problems, although these problems have been more acute in some places than others. This has been noted previously by different local observers like Koneska ${ }^{1}$ (2007), Bechev (2011) and others that have argued that there is a missing regional identity in the Southeastern Europe region, where both leaders and masses are reluctant to identify with the (Western) Balkan label, which is often connected to the symptoms mentioned above and the other remedies that are deemed simultaneous obstacles to the path of democratization, rule of law and the EU integration.

Albania, because of its idiosyncratic characteristics, it escaped unscathed the (former) Yugoslav wars and has not faced identity and nation-building challenges like its Western Balkan neighbors. These characteristics include inter alia the ethnic homogeneity and mass migration after the isolation of Communism. However, Albania has been part of the same web, with the same transition difficulties as its immediate Balkan neighbors and in some areas, like severe political antagonism, has demonstrated even a worse record that has prevented its rapid democratization and successful integration into the European Union.

${ }^{1}$ C. Koneska, "Regional Identity: The Missing Element in Western Balkans Security Cooperation." Western Balkans Security Observer. No. 7-8, 2007 . 
Because of these reasons, as well as geographical, historical and cultural, the regional identity that would have fostered a more sustainable regional cooperation between Albania and some of its neighbors has ranged from problematic to non-existent, with only recent glimpses of hope for future relations that would seek to create a notion of regional community. These include both top-dawn efforts, ranging from the series of meetings between Albania`s premier Rama and his Serbian counterpart Vucić, trying to normalize the relations between the two countries, to projects such as the Balkan Union or "Balkan Schengen", although they still are at the level of initiative and remain to be materialized. Other projects include bottom-up drives, such as the "Balkan Benelux" or trade networks such as CEFTA, with limited results. These combined efforts aim at creating what a scholar has recently named as "open regionalism"2

The EU's conditionality approach has been instrumental in the process, complimenting the U.S., NATO and other international actors role in the process of ameliorating the neighbor relations in the region and moving fast ahead with regional cooperation, hopping that it would foster a regional identity in the near future. The present paper concentrates on how regional cooperation has affected Albania and its relations with the Western Balkan neighbors and what is to be expected in the near future.

The first part of the paper analyzed and gives an overview of these concepts, by contextualizing them and also giving a sort of perspective, before discussing next the internal drives to be followed by the international pressures on the process. The fourth section concentrates on Albania's relations with its neighbors, particularly emphasizing those with Serbia, FYROM, Montenegro and Kosovo, seen from both multilateral and bilateral perspectives.

\section{Literature Review}

\subsection{Regionalism in the Western Balkans}

Regionalism is a new approach that takes into consideration the multiplicity of factors that impact the integration of a state into the intrinsic web of its most immediate neighbors. Bechev ${ }^{3}$ for example sees "regionalism as one of the prevailing trends in world politics nowadays." According to him, "regions are seen as proceeding from socio-economic linkages, but also from shared notions of belonging. There are two approaches to regional identity. The first one focuses on common culture, language, historical experience. The second approach views regions as a sort of 'imagined community' or political constructs."

The Western Balkans, which in itself is a new acronym, is often referred officially as Southeastern Europe but recently is much more a political than geographical term. It has been taken for granted that it includes former Yugoslav republics, minus Slovenia and plus Albania. But now with Croatia as part of the European Union that wants to distance itself from the club and Kosovo as a new entry, the Western Balkans is changing both in form and substance. This no doubt affects the new regional cooperation; it damages the prospects for a regional identity and places a newly invisible border between EU member countries or the ones that are on its fast track like Montenegro and the ones that lag behind due to severe political, economic and social factors, like Bosnia and Herzegovina or Kosovo. No less problematic are FYROM with the constant objection of Greece to recognize this new entity with the current official name, as well as Albania and Serbia with their political antagonism, problems of cooption and organized crime and lack of enforcement of rule of law and effective democratization process.

\section{Research Methods}

I particularly focus at certain critical junctures which I deem to have had more impact in Albania's lack of progress. To investigate the course of events in the two countries I use both discourse and content analyses. Through process tracing I investigate particular critical juncture that I render to be more significant than others to explain shifts in Albania's democratization process and analyze why the transition has been a challenge. The structure consists in a short overview of democratization process in Eastern Europe, then it focuses on Albania's transition, before it continues with an emhpasizes of external constraints. It further follows with a discussion of domestic challenges before it concludes with a summary of findings.

\footnotetext{
2 Stubbs, Paul and Christophe Solioz. "Towards Open Regionalism in South East Europe." Southeast European Integration Perspectives. Nomos, 2012.

${ }^{3}$ D. Bechev, "Contested Borders, Contested Identity: The Case of Regionalism in South East Europe." Journal of Southeast European and Black Sea Studies, vol. 4, no. 1, 2004, pp. 77-96.

${ }_{4}^{4} \mathrm{lbid}$
} 


\section{Analysis Result}

\subsection{Albania in the crossroad of regionalism of W. Balkans and EU Integration}

As stated in the introduction of this paper, Albania escaped relatively well the ghostly wars of former Yugoslavia. This happened despite the ethnic cleansing in Kosovo which led to mass deportation of Albanian brethren from their ancestral homes. But that does not mean that Albania was not suffused with the same identical problems that the rest of the region has been plagued with since, which in the case of our country in discussion, had even proliferated into metastases.

The malaise that Albania was caught into included problems with systemic corruption and state capture, lack of law enforcement and general rule of law, weak institutions and deep problems with democratization. Albania`s past legacy, its isolationism and autarchy during Communism, its multi-confessionalism system and ethnically homogeneous society clearly separated and distinguished the country from its immediate neighbors, particularly those in former Yugoslavia. Nonetheless, despite the fact that Albania escaped the mayhem that happened nearby rather unscathed, it suffered from exactly same problems, which in some cases had even worse symptoms in Albania`s case.

But some recent events encourage hopes for the betterment of relations between Albania and its former Yugoslav neighbors. For example, the resolve of Kosovo status as an internationally-recognized state, has removed the biggest source of antagonism between Albania and Serbia, despite the fact that the relationship between Kosovo and Serbia is far from being perfect. Their difficult negotiations are one reason that is precluding full recognition of Kosovo, even among EU states, which would pave the way for Kosovo to hope for candidacy status in the club in the near future.

The improvement of relations between two of the biggest antagonist states in the Southeastern Balkans history, Albania and Serbia and particularly the Albanians and Serbs in general, by removing the bone of contention, is one of the reasons for more hope for future relations that might gradually lead toward the notion of regional community. ${ }^{5}$ These include both top-dawn efforts, ranging from the series of meetings between Albania`s premier Rama and his Serbian counterpart Vucić, trying to normalize the relations between the two countries, to projects such as the Balkan Union or "Balkan Schengen", although they still are at the level of initiative and remain to be materialized. Other projects include bottom-up drives, such as the "Balkan Benelux" or trade networks such as CEFTA, with limited results. ${ }^{6}$

\subsection{The impact of international actors and factors}

We should also take into account the EU's conditionality approach that has deeply affected the cooperating process, as well as enforcing rule of law (the example of EULEX in Kosovo) or keeping general peace and fostering political cooperation (EU mission in Macedonia), or simply supervising the political class and engaging them to create state institutions (the example of Bosnia-Herzegovina). In this process, more than simply complimenting the U.S., NATO and other international actors' role in the process of ameliorating the neighbor relations in the region and moving fast ahead with regional cooperation, the EU has served as a powerful guarantee of law and order, shaping and consolidating these countries' fragile democracies. Without EU's conditionality, the democratization process would have suffered to a much larger degree as the case of Albania witnesses. ${ }^{7}$

The improvement of relations between Albania and its former Yugoslav neighbors, especially with the ones that shares an immediate border like FYROM and Montenegro but especially Serbia, can lead to more materialization of regional initiatives such as SEECP, MARRI, CEFTA and other regional organizations, as well as newly proposed institutions like Balkan Schengen or Balkan Benelux. As stated above, this leads to the reasonable hope that it would foster a regional identity in the near future.

\section{Discussion}

Regional cooperation has taken off from very rough start and most difficult historical circumstances. Only in twentieth century we faced two world wars, whose genesis could be traced into this volatile region that nowadays we conveniently

51. Kalemaj, "Challenges and opportunities in the Western Balkans: Albania in the crossroad of regional versus European integration." Paper presented at Regional Cooperation and Regional Identity in the Western Balkans: Similarities and Differences conference, Centre for EU Neighborhood Studies (CENS) of the Central European University (CEU) and the Andrássy Forum for Western Balkan Studies, Budapest, Hungary. May 232016.

6 Ibid

${ }^{7}$ A. Elbasani, "Albania in Transition: Manipulation or Appropriation of International Norms?" Southeast European Politics, vol. 5, no. 1, 2004, pp. 22-44. 
refer as the Western Balkans. The Southeastern Europe rocky road toward stability has proven to be shaken once again toward the end of $20^{\text {th }}$ Century, right after the collapse of Communist era and the fall of the Berlin Wall. The ethnic cleansing, war crimes and irredentist projects that followed, not only proved to be an additional burden to already problematic process of cooperation that was coming under heavy pressure even among the fragile framework of Yugoslavia, but they quickly deteriorated the barely existing relations between Albania and its immediate (former) Yugoslav Republics' neighbors.

As such, the search for a common post-Yugoslav regional identity that would be simultaneously inclusive and overarching, was daydreaming at best and perceived to be irrational thinking even by most open minded observers. However, the last decade has proven critical to overcome many of the suspicions of the past and to greatly push toward regional cooperation. European integration process has been the main instigator, as well as the role and the presence of the US, UN, NATO, OSCE, Council of Europe, Contact Group and other reliable Western partners, heavily invested into fostering peaceful relations among one of the most volatile regions in the world. As a result, the newly institutions, such as UNMIK, EULEX were complemented by regional initiatives such as CEFTA, MARRI, Balkan Schengen initiative etc. ${ }^{8}$

On the other hand, countries like Croatia, Albania and recently Montenegro have joined NATO, while also making significant progress toward EU integration. Croatia already joined EU as a full member of this exclusive club, while Montenegro and Serbia have already opened the negotiations for the chapters that have to be fulfilled before full accession. Albania is next in line, hoping to do so in the next couple of months, while FYROM's progress in both EU integration trajectory and NATO membership are blocked by the Greek veto, because of the name dispute. BosniaHerzegovina suffers from the dysfunctionality of a problematic constitutional framework and deep institutional problems that result Dayton agreement that terminated the conflict in B-H. Kosovo as a new state and not fully recognized even within EU context because five member states still have to recognize it, is in the process of application for visa liberalization and hopefully in the coming years to apply for the candidacy status.

\section{Conclusion}

The present paper shows how regional cooperation has already affected Albania and its relations with the Western Balkan neighbors and what is to be expected in the near future. This is in tandem with how Albania is rapidly improving its standing in the relations with its immediate neighbors, as well as how it contributes to the regional stability. However, cooperation still suffers from mutual lack of faith and open problems among different W. Balkan countries. Kosovo is still a bone of contention in the relations between Serbia and Albania, not to mention the problematic that exists between Kosovo and Serbia themselves, irrespective of the brokerage role that Brussels is playing in the process. The existing problems between Greece and FYROM, Serbia and Croatia, Montenegro and Kosovo regarding the agreement on the border follow into the steps of Croatia and Slovenia previous border problems. These in themselves are only some of the problems that preclude full regional integration.

Thus moving toward a regional post-Yugoslav identity still remains a challenge that has to be solved with or irrespective of European integration process. This process in itself presupposes different speeds of the region's countries and does not help a priori to enhance greater trust and willingness to move ahead with regional integration process among these prospective EU candidates.

\section{References}

Anastasakis, Othon \& Vesna Bojicic-Dzelilovic. 2002. "Balkan Regional Cooperation \& European Integration," The Hellenic Observatory. The European Institute. The London School of Economics and Political Science.

Bechev, Dimitar. 2004. "Contested Borders, Contested Identity: The Case of Regionalism in South East Europe." Journal of Southeast European and Black Sea Studies, vol. 4, no. 1, pp. 77-96.

Cottey, Andrew. 2009. "Sub-Regional Cooperation in Europe: An Assessment," Bruges Regional Integration \& Global Governance Papers.

Curri, Fatmir and Mimika Lloshi. 2014. "Monitoring Regional Cooperation in South East Europe: Country Report- KOSOVO." Monitoring Regional Cooperation in South East Europe. Friedrich Ebert Siftung, Berlin, Germany.

Elbasani, Arolda. 2004. "Albania in Transition: Manipulation or Appropriation of International Norms?" Southeast European Politics, vol. 5, no. 1, pp. $22-44$.

Kalemaj, llir. 2016. "Challenges and opportunities in the Western Balkans: Albania in the crossroad of regional versus European

${ }^{8}$ O. Anastasakis and Vesna Bojicic-Dzelilovic. "Balkan Regional Cooperation \& European Integration," The Hellenic Observatory. The European Institute. The London School of Economics and Political Science, 2002. 
integration." Paper presented at Regional Cooperation and Regional Identity in the Western Balkans: Similarities and Differences conference, Centre for EU Neighborhood Studies (CENS) of the Central European University (CEU) and the Andrássy Forum for Western Balkan Studies, Budapest, Hungary. May 23.

Koneska, Cvete. 2007. "Regional Identity: The Missing Element in Western Balkans Security Cooperation." Western Balkans Security Observer. No. 7-8.

Stubbs, Paul and Christophe Solioz. "Towards Open Regionalism in South East Europe." Southeast European Integration Perspectives. Nomos, 2012. 
ISSN 2039-2117 (online)

ISSN 2039-9340 (print)
Mediterranean Journal of Social Sciences MCSER Publishing, Rome-Italy
Vol 7 No 6 November 2016 